Article

\title{
The Experience of Consciousness: The Architectonic of the Grundlage der gesammten Wissenschaftslehre
}

Ronnie Mather

The key work of the early Johann Gottlieb Fichte (at least in regard to the interpretation of his system) is the Grundlage ser gesammten Wissenschaftslebre [Foundation of the Entire Doctrine of Science] of 1794-95. The very circumstances of its publication ensure that it is a rather terse and disjointed statement of Fichtean philosophy. It consists of a very short preface, a "famous" (at least in the sense of actually being read) section devoted to first principles, the so-called "basic propositions of the entire doctrine of science," and eight discourses of widely diverging length. The first discourse, devoted to the "theoretical" Wissenschaftslehre is one and a half times the length of the other seven. The third, fourth, fifth, sixth and eighth are barely a few pages long. It is an extremely peculiar work and not merely due to the circumstances of its publication. Its very argumentative structure threatens to trap the reader in forming hasty and preliminary judgements on the exact nature of the philosophical claims being made, and, quite specifically, those philosophical claims which might be ascribed to the author himself. The following contends that lack of attention to the structure of a work that, admittedly, exhibits very little in an overt fashion has led to wholesale confusion about the early system and its philosophical intent. Specifically, that too much attention has been paid to the famous section on grounding principles, and, furthermore, that attention only to these sections will lead to fundamental confusion and misunderstanding. This paper will attempt to examine this peculiar Fichtean text via the readings made by Dieter Henrich and Frederick Neuhouser, respectively.

\section{Henrich on Fichte}

One of the most influential readings of Fichte in recent years has been that of Dieter Henrich in Fichtes ursprungliches Einsicht. ${ }^{1}$ The latter constitutes an attempt not only to rehabilitate Fichte as a thinker in his own right, but also to

1 Dieter Henrich, Fichtes urprungliches Einsicht (Frankfurt: Klosterman, 1967). Translated by D. R. Lachterman, "Fichtes Original Insight," in Contemporary German Philosophy, 1:9 (1982). 
relate Fichte to contemporary debates on the nature of self-consciousness. According to Henrich, Fichte was possessed of a unique insight into the difficulties and possibilities of the concept of self-consciousness, an insight largely overlooked. This has been carried further by Manfred Frank in his influential work $W$ as ist Neostrukturalismus?2 who takes Fichte to hold a theory of self-consciousness which circumvents much of the Heideggerian critique of subjectivity. Henrich makes very strong claims on Fichte's behalf-“Anyone seeking a suitable concept of self-consciousness must go back to Fichte and the knowledge he achieved"3 Henrich's reading, as he himself states, "takes its bearings more from the issue than the text." 4 That issue is self-consciousness itself. Or, rather, a particular structure of self-consciousness that Western thought up to and including Kant had presupposed. That is, "the reflection theory" of self-consciousness. All previous theories of self-consciousness had operated with a model of self-hood extrapolated from knowing the objective world. The self, abstracting from the perceived world, turns back into itself and makes itself the object of enquiry. There is no purported difference between that which investigates (the self) and the object under investigation (the self); that, precisely, is what makes self-consciousness such a unique object of investigation, I = I, perfect subject-object identity. Such a theory, as Kant was well aware, must always presuppose the self- "Thus we can only revolve around it in a perpetual circle." 5 The "reflection theory" of self-consciousness then presupposes two things, there is a self, and that this self can stand in a common relationship to itself by making itself subject-object.

This theory according to Henrich exhibits grave deficiencies. Selfconsciousness, that is, the self knowing itself comes about through an act, the act of turning back from the world and making the self the object of investigation. Only in and through this activity is self-consciousness possible. That is, self-consciousness is possible only when the self makes itself an object of enquiry and states "I am I," makes itself an object and takes possession of that object. That is the very origin of self-consciousness. But it can be stated with equal precision that such an origination is impossible. For "reflection" can be understood as nothing other than the rendering explicit of what is already present; reflection can bring nothing into being that is not already to hand in some guise or other. Self-consciousness cannot originate in an act of reflection. That which is to come about through reflection, self-consciousness, must always be presupposed. The act, of turning back into oneself, of making oneself an object, is therefore irrelevant, self-consciousness is always already "there"- "the subject of reflection on its own thereby satisfies the whole equation I $=\mathrm{I}$. Yet reflection alone was supposed to bring about this equation." It might be thought possible to save the "reflection theory" by

2 Manfred Frank, Was ist Neostrukturalismus? (Frankfurt: Suhrkamp, 1983). Translated

by R. Gray, What is neo-Structuralism? (Minneapolis: University of Minnesota Press, 1989).

${ }^{3}$ Henrich, op cit., 18

${ }^{4}$ Ibid.

${ }^{5}$ Ibid., 20.

${ }^{6}$ Ibid. 
asserting that the subject-self, the self about to undertake the act of objectifying itself, is somehow different from that which actually performs the act, becomes subject-object. That is, self-consciousness consists in, or rather as, the product of this act. However, the importation of difference into the equation $\mathrm{I}=\mathrm{I}$ is only possible at the expense of the identical self itself. If that which is to be regarded as subject-self is to be distinguished from the self that objectifies itself could the equation I = I ever hold? There is here seemingly an inescapable dilemma for the reflection theory of self-consciousness. The latter holds that self-consciousness arises through the self knowing itself as object. The question is how can such an object-self be distinguished from the self attempting to become conscious of itself (the subject-self)? If it can be so distinguished then it is obviously the case that it is not the self as such that is the object of its enquiry. If it cannot be so distinguished, then any proposed enquiry into the origin of self-consciousness must always presuppose that origination rather than offering an explanation thereof.

The problem of circularity does seem endemic to a reflection theory of self-consciousness, "it can only ignore this circle, it can never escape from it." 7 And, potentially fatal if one holds, like Henrich, that "the reflection theory of the self wants to explain the origin, not the clarity, of self-consciousness." Such a theory, as Henrich points out, is also subject to an infinite regress. If the self knows itself through making itself object then it knows itself only through this self-relation. There is no "third thing" through which such a relation first becomes possible. How then is self-consciousness possible? Or, rather, how can a first moment of self-consciousness be possible? The self objectifies itself, turns back into itself, and claims self-awareness. How can it be sure that what it has grasped is the self, the self as object? Selfconsciousness only arises through this act. But, how does it know what it has grasped is the self itself? Only if previous acquaintance with such an object-self is presupposed- "the theory of reflection begs the question once again. It presupposes that the problem which it has been faced with has been completely solved at the start"'. According to Henrich, Fichte was the first philosopher to recognise the circle itself and its concomitant consequences. These consequences would culminate in a pre-reflexive notion of the self (Fichte's "original insight"), presented in the differing formulae of the various versions of the Wissenschaftslehre. In regard to the text of 1794-95, the prereflexive notion of subjectivity is expressed in the terms that "the self posits itself absolutely and unconditionally." Henrich interprets the claims concerning self-positing [setzen] as an attempt to formulate a theory of selfconsciousness which avoids the circularity endemic to the "reflection theory." The latter was condemned to presuppose that which it sought to explain, namely the origination of self-consciousness. "Positing" is an attempt to foreclose this difficulty, Fichte postulating the existence of an I which comes

$$
\begin{aligned}
& { }^{7} \text { Ibid. } \\
& { }^{8} \text { Ibid. } \\
& { }^{9} \text { Ibid., } 21 .
\end{aligned}
$$




\section{THE EXPERIENCE OF CONSCIOUSNESS}

into being only in and through this activity. No previously existent subject-self need or should be posited. The identical subject-object, I = I, is posited "all at once." The reflection theory would have to enquire what does the positing and so be caught in a possibly infinite regress. Henrich's Fichte would answer, the self is the posting. Nothing precedes positing. In the words of the Grundlage der gesamten Wissenschaftslehre which Henrich himself surprisingly does not quote "the self begins by an absolute positing of its own existence." 10 Henrich states- "Fichte's term 'positing,' which he never defined, is well suited to formulate both these points at once: First, something emerges absolutely without having previously existed and, second, in emerging it enters into a relation with knowledge. What posits itself absolutely comes to be for itself without requiring any further basis." 11 Henrich traces the further development of this fundamental insight in the later versions of the Wissenschaftslehre.

Henrich's argument is as masterful as it has been influential. The difficulty lies not in the possibility or even desirability of a critique of the "reflection theory" of self-consciousness or even in the claim that setzen can be regarded as a successor-concept to that theory but in the larger assumptions implicit in Henrich's essay. Primarily, the assumption that the activity of setzen constitutes the definitive or dominant theme of Fichte's thinking with regard to self-consciousness. Henrich, and it might be added the majority of Fichte's commentators, mistakes a preliminary statement on the nature of selfconsciousness (the activity of setzen itself drawn from the section devoted to the "basic propositions"), for the proper and fully elaborated theory of primordial subjectivity actually espoused by Fichte. A major flaw of much Fichte-interpretation, classical and contemporary, lies in the over reliance on that section of the text devoted to the "basic principles of the Doctrine of Science" (the famous Grundsatze"). Henrich takes the claims concerning subjectivity elaborated therein as Fichte's definitive insight. In actual fact, the definitive characterisation of primordial subjectivity would not occur until much later in the Grundlage. And that primordial subjectivity is very different in nature from the activity denoted by "positing." Indeed, Fichte explicitly concedes that the I as a self-positing activity cannot function as a "grounding" activity of systemic idealism. In actual fact, the concept of subjectivity, actually operative in the G.W., is roughly similar to the "reflection theory" of which Henrich is so disparaging. Ironically, Fichte is part of the problem and not the beginning of the solution (assuming specific reference to the Grundlage and that the reflection theory is problematic). I hope to demonstrate that this is not simply a matter of arbitrarily privileging one section of the text over another but that the structure of the text itself is the key to its interpretation. We now turn to Neuhouser's interpretation of the G.W.

${ }^{10}$ J. G. Fichte, Grundlage der gesamten Wissenschaftslehre, als Handschrift für seine Zubörer, Philosophische Bibliothek, Band 246 (Hamburg: Meiner Verlag, 1997), 99. Translated by Peter Heath and John Lachs as The Science of Knowledge (Cambridge: Cambridge University Press, 1982).

${ }^{11}$ Henrich, op cit., 25. 


\section{Neuhouser on Fichte}

F. Neuhouser's Fichte's Theory of Subjectivity ${ }^{12}$ is one of the most recent and extensive treatments of the early system in English. Other treatments on discrete areas, such as R. Williams ${ }^{13}$ on the subject of recognition and the collection edited by $\mathrm{D}$. Breazeale \& T. Rockmore ${ }^{14}$ have made valuable contributions. Neuhouser attempts to chronicle both the historical development of Fichte's thinking from 1790 to 1799 and offer a reconstruction of Fichte's theory of subjectivity based on the texts of this period. His point of departure is the Kantian dichotomy between theoretical and practical reason and the ultimately unresolved question of their unity. There is, what Neuhouser terms a pre-systematic period, roughly 1790-94, where Fichte argues that theoretical and practical reason are compatible. Then a middle period, 1794-97, where theoretical and practical reason are derived from a single principle. The third period is marked by the arrival of the so-called Wissenschaftslehre novo methodo where practical and theoretical reason are said to possess an "identical structure." Neuhouser is plainly of the opinion that the G.W. is a failure, its project of deriving a system from one principle illconceived, "it belongs to that class of German Idealism's claims that, though philosophically provocative are almost certainly incapable of being carried out." 15 Neuhouser's account of the Grundlage is given in just over ten pages. It contains one moment of definite insight; namely, that there is "a basic conflict between the content of the first principle as articulated in section 1 of the WL of 1794 and the way in which Fichte actually uses this principle throughout the work." 16 This conflict is well noted. Neuhouser's general account of the failure that is the G.W. stems from the nature of its two fundamental principles. The first principle is identified, initially, in terms of the activity of setzen, an activity that Neuhouser identifies in terms reminiscent of Henrich, an activity that inheres in nothing, it is what it enacts, and is only when it acts. The second principle, the famous counter-positing of the not-I by the $\mathrm{I}$ is again handled well by Neuhouser within the interpretative context of that text devoted to the Grundsatze. The facticity of human limitation, it turns out, can never be explained on the basis of a not-I posited by an I. Only a qualitatively opposed not-I (thing-in-itself) can sufficiently account for the finitude inherent in human reflection (though Fichte's reader would never gauge that purely from reading that section devoted to counter-positing in the Grundsatze). The attempt, therefore, to account for that finitude as a result of the activity of the subject, the project of the theoretical Wissenschaftslebre, is doomed to failure. Again, perfectly correct.

${ }^{12}$ F. Neuhouser, Fichte's Theory of Subjectivity (Cambridge: Cambridge University Press, 1990).

${ }^{13}$ R. Williams, Recognition: Fichte and Hegel on the Other (Albany: SUNY Press, 1992).

${ }_{14}$ D. Breazeale and T. Rockmore, Fichte: Historical Contexts/Contemporary Conrtoversies (New Jersey: Humanities Press International, 1994).

${ }^{15}$ Neuhouser, op cit.,68

16 Ibid., 43. 


\section{8}

\section{THE EXPERIENCE OF CONSCIOUSNESS}

The problem with Neuhouser's approach begins with his reading of the practical Wissenschaftslehre. Neuhouser reads this as generated through a fundamental contradiction between the results of the theoretical Wissenschaftslehre, that is, the activity of reflection is dependent upon a qualitatively opposed not-I, with a re-defined first principle- "The import of the first principle here, it would seem, is to assert that the essence of the I lies in its self-sufficiency, that it is the nature of the I to be completely independent of the not-I or, in other words, to be wholly self-determined and undetermined in any way by its object. And, if the first principle is understood in this way, it becomes apparent why Fichte regards it as conflicting with the theoretical subject's dependence upon an anstoss. ${ }^{17}$ The dependence of the I with regard to the activity of reflection would appear to foreclose the possibility of the I being self-sufficient and independent. Both principles taken together contradict one another. The practical Wissenschaftslehre is an attempt to overcome this contradiction. If the I, through the activity of practical reason, could be said to have some causality upon the not-I, then the I could be said to be selfsufficient (albeit in a rather roundabout way). However, this solution, or attempted solution, jeopardises the independence of the second principle, that the not-I be utterly opposed to the I. Thus the causality of the I upon the notI is reduced to the status of mere striving [streben]. The I "demands" that the not-I be in conformity with the not-I, a demand that is never completely attainable - "the principle of striving is intended to take into account the ineradicable finiitude of the subject expressed in the second principle, while still attributing to the $\mathrm{I}$ an absolute quality that, by the end of the Wissenschaftslehre, is understood, not as a fact about the subject, but as a demand that the I makes upon itself and its world."18

The problem with this reading is quite simple. Such an argument is present in the text. And it is present in the form Neuhouser outlines $(1,246-$ 70). ${ }^{19}$ The problem once more is the peculiar structure of the text itself. Neuhouser has presented Fichte's understanding of the neo-Kantianism of his day as Fichte's own philosophical position, the very position the G.W. was intended to supersede. Fichte's own position is present within, and only within, the last section of the Grundlage (1,271-328). Anything out with that section, should be treated with caution if being taken as indicative of Fichte's own position.

\section{Interpreting the Grundlage of 1794-95}

The critique of Henrich may strike the reader as implausible for a variety of reasons, most notably Fichte's own insistence on the activity of setzen as avoiding the sceptical attacks of the type Schulze launched on Reinhold's

${ }^{17}$ Ibid., 49.

18 Ibid., 51.

19 I refer here to the Werke pagination which is still extensively used in Fichtescholarship: Fichtes Werke, 11 volumes, edited by I. H. Fichte (Berlin: de Gruyter, 1971). 
facts of consciousness. The "facts" were replaced by the act, [Tathandlung]. The first principle of the Wissenschaftslehre must be self-positing activity, the Aenesidemus Review "transformed" German Idealism ${ }^{20}$ and Fichte continued to insist throughout the works of this time that self-positing and intellectual intuition were the very basis of any possible idealist system. That is undoubtedly what he says but not what he does. I am of the opinion that Schulze's critique of Reinhold had a baleful effect on both Fichte's thinking and subsequent generations of Fichte-interpretation. For the purposes of the Grundlage (and is mentioned only once, in the Preface, 1,95) the question of intellectual intuition is irrelevant. To put it bluntly, either Fichte changed his mind or found that the trumpeted first principle of self-positing could not do the job required, that is, ground a system of idealism. The impact of Schulze's critique of facticity may have led him to propose a first principle with such a fanfare that he could not drop it. The real key to the Grundlage and much of the other work of this time actually lies in the following passage from Martin Heidegger:

The world picture does not change from an earlier mediaeval one into a modern one, but rather the fact that the world becomes a picture [Bild] at all is what distinguishes the essence of the modern age. For the middle ages, in contrast, that which is, is the ens creatum, that which is created by the personal creator-God as the highest cause. Here, to be in being means to belong within the specific rank of the order that has been created - a rank appointed from the beginning - and as thus caused, to correspond to the cause of creation (analogia entis). But never does the Being of that which consists here in the fact that it is brought before man as the objective, in the fact that it is placed in the realm of man's knowing and of his having disposal, and that it is in being only in this way. ${ }^{21}$

Fichte is the modern thinker par excellence. That which "is" has "being" is capable of being represented, imagined, copied, pictured. The Wissenschaftslehre is the philosophy of "picture-thinking" [Vorstellung]. Not just the philosophy of picture-thinking but also philosophy as picture-thinking. The real significance of the Grundlage. is that it constitutes the last attempt to reconcile a philosophy of humankind as "ens creatum," the highest cause, with the new philosophy of representation. It is an attempt to reconcile the selfconsciousness of God, the primordial subjectivity of humankind (both are one

\footnotetext{
${ }^{20}$ D. Breazeale "Fichtes Aenesidemus Review and the Transformation of German Idealism," in Review of Metaphysics, 34 (1981).

21 Martin Heidegger, "The Age of the World-Picture," in The Question Concerning Technology and Other Essays, trans. by W. Lovitt (London: HarperCollins, 1977), 130.
} 


\section{THE EXPERIENCE OF CONSCIOUSNESS}

and the same) with a philosophy of picture-thinking, a negotiation between a creative I and the pre-existent world of represented material objects.

The key to the Grundlage is that Fichte presupposes that human beings operate, and can only operate, as representational imaging beings. To put it crudely, they think, and can only think in pictures. That is true whether of immediate cognition or the highest levels of philosophical abstraction. It follows then that any series of philosophical reflections or abstractions which are committed to print, and committed to the instruction of others, must be put forward in the form accessible to imagining, representing beings. That is, as a series of images which they can construct, imagine, picture, for themselves. The real is the imaginable and the imaginable is the real. Philosophising is

The business of the creative imagination, a faculty which all men are certainly endowed with, since without it they would have no presentations at all: though by no means all of them have it at their command, to create therewith in a purposeful manner, or if, in a fortunate hour, the required image should seize it, to examine it, and to register it inerasably for any use they wish. It is this power which determines whether we philosophise with insight. The Science of Knowledge is of a kind that cannot be communicated by the letter merely, but only through the spirit; for its basic ideas must be elicited in anyone who studies it, by the creative imagination itself.....the whole enterprise of the human spirit issues from the imagination, and the latter cannot be grasped save through the imagination itself. ${ }^{22}$

The Grundlage consists in and through a series of images elicited in the imagination of Fichte's reader by Fichte's text. This is true of both of the main sections of the Grundlage and is immediately apparent even on the most superficial reading of the text. The condition that a philosophical abstraction or a philosophical reflection be literally imaginable is the determining condition of its intelligibility.

The Grundlage is essentially a series of thought-experiments or a series of invitations to create a map of subjectivity, a cartography which maps the terrain between the creative I (which we will come to shortly) and brute material reality which induces the famous Anstoss. Fichte operates with two distinct conceptions of not-I. When he refers to the I positing not-I (and this constitutes the vast majority of cases) then he is always referring to the part played by the finite I in the constitution of its representations. It is not-I as material reality that occasions most of the difficulties. This is the not-I that induces the check, the ultimate source of our system of representations. It transcends representation, it cannot be imagined. But it can reveal itself

${ }^{22}$ Fichte, The Science of Knowledge, 250. 
through feeling. The major reason why Fichte has been subject to the scale of misrepresentation he has suffered is largely due to the paucity of his references to absolute not-I, probably because of the difficulties experienced by Kant in regard to the thing in itself. It is the space within the absolute limits of I and absolute not-I that the Wissenschaftslehre attempts to chart.

Posit a continuum between two points A (I) and B (not-I). Assume an occupied space between them, but assume that the not-I does not begin until point B. What fills that space? Presumably A, the I, subjectivity. That is in fact the case. Everything that the $\mathrm{I}$ is, everything that subjectivity is, everything that the I can know, is within A and B. Fichte may not be a subjective idealist in the ridiculous sense of believing that matter is somehow the result of an active I. However, he is committed, seemingly, to the claim that everything that the I can experience, can know, is somehow already within the $I$ and that which is not-I is completely unknowable. For all practical purposes that is subjective idealism. But that is inaccurate for two reasons. Firstly, there is awareness of not-I through feeling, touch (Fichte would have thoroughly approved of Dr Johnson kicking the stone). Secondly, and most importantly at this particular juncture, the space between I and not-I must not be understood as actual, finite, human subjectivity. It must be interpreted as a primary ground force inherent in all human beings, in the terms of the Grundlage., an "outgoing" [Herausgehen] moving along the continuum A/B until it encounters point B, absolute not-I.

Picture a primordial force encountering a qualitatively opposed not-I. What will occur? Fichte's Grundlage posits a recoil of activity from B along the continuum A/B. Such a recoil, or shock of opposition is evinced, and can only be evinced, by a feeling of "compulsion" [Zwanges] that all human beings encounter in regard to perception (of being "forced" as it were to represent objects as they present themselves). The activity that reverts back into the I Fichte terms the "presentational drive" [Vorstellungstrieb]. The I cannot create the world merely represent what is there through the activity of after-imaging [Nachbilden]. There then arises self-feeling [Selbst-gefubl, a dual feeling of limitation, occasioned by the check, and "longing" [Sehnen], a feeling of being driven toward the unknown. The latter is a remnant of the original outgoing activity though the finite $\mathrm{I}$ is unaware of this. Longing is the most primitive form of self-awareness though consciousness proper has not yet arisen. Through a series of unconscious reflections, longing comes to posit, absolutely, that the activity of re-presentation [Nachbilden] is something other than itself. Though this activity it becomes sensation. That which is sensed is further determined by the imagination. It is the absolute positing of this region of sensation that has caused most of the difficulty around the reality of material nature. That region is posited by an absolute act of the I but it has already been subject to the activity of primordial subjectivity [Nacbbilden]. The I as intellect only comes into being after or through the positing of the region of sensation. That is why it regards sensation as somehow foreign or alien but, equally, as something within or for the I. Longing, by an absolute act, posits something already within the I considered as primordial subjectivity, as outside 


\section{THE EXPERIENCE OF CONSCIOUSNESS}

the I considered as finite subjectivity. That which is sensed is not-I as it exists for the finite I. That I takes it to be something foreign because it is not aware of the activity. Only with the positing of a region of sensation is the basic picture of Fichtean subjectivity complete. The early system then completes the map of subjectivity by mapping on the various drives Fichte identifies throughout the early work onto this models. The drives are the emasculated remnants of the original creative force, the activity of representation is further determined. The Grundlage is a gallery of such images, a map constructed by the mind of the reader.

\section{The First Principle of the Wissenschaftslehre}

Fichte's own philosophical position only arrives in the Grundlage towards the end of the second discourse and I believe there are very good reasons for supposing that its first principle is very far removed from the activity denoted by setzen. What then is the first principle? The very question is ill-conceived. The proper question is How can that first principle be imagined or pictured? The key to the Grundlage lies in the condition of its possibility in the mind of that human being described by the system itself. That is, a human being capable only of thinking in images or pictures. This is not an arbitrary hermeneutic move as the first thing Fichte does is to inform his reader of this:

On the strictest interpretation, the picture of the self, in our present mode of envisaging it, is that of a selfconstituting mathematical point, in which we can distinguish no direction or anything else whatsoever; which is altogether where it is, and whose content and limits (substance and form) are one and the same. If the nature of the self contains nothing other than this constitutive activity alone, it is what everybody is for us. ${ }^{23}$

The above is clearly intended as a reference to the activity of setzen. The I consists in, and of, nothing but its own activity. But can such an activity be imagined or pictured? And can it do the job required? The answer to both is surely in the negative. Henrich's claim that setzen remains rather poorly defined is almost irrelevant. The first principle of the Wissenschaftslehre must stand under the condition of all human thinking, that is, it must be capable of being imagined or pictured. Therefore, it must be pictured as traversing some space. This Fichte refers to as the Herausgehen going outside or beyond oneself.

The self posits itself absolutely, and is thereby closed to any impression from without. But if it is to be a self, it must also posit itself as self-posited; and by this new posting, relative to an original positing, it opens itself, if I

23 Ibid., 241. 
may so put it, to external influences; simply by this reiteration of positing, it concedes the possibility that there might also be something within it that is not actually posited by itself. 24

That is Fichte's "big bang" that blows apart the self-constituting mathematical point that is setzen. In more modern parlance, setzen is the "singularity" that blows apart to form the subjective universe. The I must be pictured as extending from one positing point to another positing point, that is, occupying some spatial location. Positing is an uncaused activity, the outgoing activity must likewise be posited as uncaused. It must have its own source of movement within itself (the so-called striving for causality in general). In positing itself as self-posited, as going beyond itself it "reflects" on itself as self-posited. Fichte states that this is not real reflection. No distinction can be made between the subject of that reflection and its object. What has been described is "the self-consciousness of God" (assuming that God reflects on his own existence)." 25 Two things need to be noted. Fichte does operate with a version of a reflection theory of subjectivity, Henrich's influential reading notwithstanding. Secondly, Hegel's famous remark in the Science of Logic that "this content is the exposition of God as he is in his eternal essence before the creation of nature and a finite mind" 26 intends to recollect in his readers minds the claim made above before replacing Fichte's drives with the "concept."

All of this can be read as a regression back into the rationalist tradition, the "scienta intuitiva" of Spinoza's God or the "intellectus archetypus" which Kant described to Herz. ${ }^{27}$ In actual fact, it is nothing of the sort. It does not describe any actual human subjectivity, in an unpublished text of around this time Fichte refers to this "outgoing" as "the primary force in man." 28 Nevertheless, this outgoing or primary force cannot be reckoned to be a mere abstraction. It does exist. But once more, it can be evinced only through being checked, and, subsequently, "felt." That is why the Wissenschaftslehre appeals to feeling as well the imagination throughout. It is our contention that attention to the operative principle of the Wissenschaftslehre can yield only one conclusion; that is, that the entire debate on the nature of intellectual intuition, perhaps the dominant intellectual theme of the debate on Fichte, has been wasted academic labour (at least in relation to Fichte's own philosophical position). Intellectual intuition was clearly conceived of as some sort of answer to the purported first principle, setzen, being subject to the kind of Schulzean

\footnotetext{
${ }^{24}$ Ibid., 243.

25 Ibid., 242

${ }^{26}$ G. W. F. Hegel, The Science of Logic, trans. by A. V. Miller (Oxford: Oxford University Press), 51.

27 Immanuel Kant, Philosophical Correspondence, ed. and trans. by A. Zweig (Chicago: Chicago University Press, 1967).

${ }^{28}$ J. G. Fichte, "On the Spirit and Letter in Philosophy in a Series of Letters," in German Aesthetic and Literary Criticism: Kant, Fichte Schelling, Schopenhauer, Hegel ed. and trans. by E. Rubenstein (Cambridge: Cambridge University Press, 1984), 80.
} 


\section{THE EXPERIENCE OF CONSCIOUSNESS}

attack that would reduce it to just another (contestable) fact. But we would suggest that the Fichtean system had already outgrown the first principle that Fichte had announced with such fanfare, indeed that the entire project announced in Fichte's short "prolegomena," Ueber den Begriff der Wissenschaftslehre (1794) was never actually undertaken. The obsession with intellectual intuition and system has tended to obscure the fact that the Grundlage. and its sister volume the Grundriss is more concerned with a theory of consciousness rather than self-consciousness. It may be more profitable to read the Grundlage as answering "the historical question of philosophy" that Fichte outlines in his infamous Vergleichung des vom Hrn Prof.Schmid aufgestellten Systems mit der Wissenschaftslehre published in 1796. This contains the notorious "act of annihilation" but it also contains the clearest statement of what Fichte takes "philosophy" to be after the abandonment/suspension of the project announced in 1794-that is the connection between "representations and things." This little text repays close scrutiny.

In my opinion, the following question is the one which philosophy has to answer: what is the connection between our representations and their objects? To what extent can we say that something independent of our representations, something altogether independent of and external to us, corresponds [entsprechen] to our representations. This is a historical claim, in support of which I appeal to the better contemporary philosophical authors, as well as to the entire history of philosophy. ${ }^{29}$

It is our contention that the Fichte of the G.W. is already concerned with this task and that the G.W. is a "science of the experience of consciousness" rather than a system derived from an intuited principle of selfconsciousness. It is the primary ground force of man encountering the reality of material nature that constitutes the basis of the Fichtean system and a fundamental reorientation in favour of an anthropological reading of the early Fichte is long overdue.

Centre for Distance Learning, Empire State College - State University of New York, United States

\section{References}

Breazeale, D., "Fichte's Aenesidemus Review and the Transformation of German Idealism," in Review of Metaphysics, 34 (1981), 545-68.

${ }^{29}$ J. G. Fichte, "Comparison of Prof Schmid's System with the Doctrine of Science," in Fichte: Early Philosophical Writings, ed. and trans. by D. Breazeale (Cornell University Press, 1993), 317. 


\section{R. MATHER 115}

Breazeale, D. and Rockmore, T., Fichte: Historical Contexts/Contemporary Controversies (New Jersey: Humanities Press International, 1994).

Fichte, J. G., The Science of Knowledge, trans. by P. Heath and J. Lachs (Cambridge: Cambridge University Press, 1982).

, "On the Spirit and Letter in Philosophy from a series of letters," in German Aesthetic and Literary Criticism: Kant, Fichte, Schelling, Schopenhauer, Hegel, ed. and trans. by E. Rubinstein (Cambridge: Cambridge University Press, 1984).

"Comparison of Prof. Schmid's System with the Doctrine of Science," in Fichte: Early Philosophical Writings, ed. and trans. by D. Breazeale (Ithica NY: Cornell University Press, 1993).

Frank, M. and Wilde, S., What is NeoStructuralism?, trans. by R. Gray, (Minneapolis: Minnesota University Press, 1989).

Hegel, G. W. F., The Science of Logic, trans. by A. Miller (Oxford: Oxford University Press, 1969).

Heidegger, M., "The Age of the World-Picture," in The Question Concerning Technology and other Essays, trans. by W.Lovitt (London: HarperCollins, 1977).

Henrich, D., "Fichte's Original Insight," trans. by D. Lachterman, in Contemporary German Philosopby Volume 1, ed. by D. Christensen (Pittsburgh: Pennsylvania State University Press, 1982), 15-53.

Kant, I., Philosophical Correspondence: 1759-1799, ed. and trans. by A. Zweig (Chicago: Chicago University Press, 1967).

Neuhouser, F., Fichte's Theory of Subjectivity (Cambridge: Cambridge University Press, 1989).

Williams, R., Recognition: Fichte and Hegel on the Other (Albany: State University of New York Press, 1992). 